\title{
Highly efficient epoxidation of alkenes with m-chloroperbenzoic acid catalyzed by nanomagnetic $\mathrm{Co}(\mathrm{III}) @ \mathrm{Fe}_{3} \mathrm{O}_{4} / \mathrm{SiO}_{2}$ salen complex
}

\author{
ALI ALLAHRESANI* and MOHAMMAD ALI NASSERI \\ Department of Chemistry, Faculty of Sciences, University of Birjand, P. O. Box 97175-615, Birjand, Iran \\ Email: a_allahresani@birjand.ac.ir; manaseri@birjand.ac.ir
}

MS received 25 August 2016; revised 7 November 2016; accepted 29 December 2016

\begin{abstract}
A new type of heterogeneous Co(III) complex was synthesized by covalent grafting of homogeneous $\mathrm{Co}$ (III) salen complex onto the surface of $\mathrm{Fe}_{3} \mathrm{O}_{4} / \mathrm{SiO}_{2}$ nanoparticle (NP). The heterogeneous nanocatalyst was characterized by X-ray diffraction (XRD), thermogravimetric analysis (TGA), transmission electron microscopy (TEM), Fourier transform infrared spectra (FT-IR), atomic absorption spectroscopy (AAS), vibrating sample magnetometer (VSM) and nitrogen adsorption-desorption isotherm (BET). The catalytic activity was investigated for the epoxidation of alkenes using m-chloroperbenzoic acid as oxidant at room temperature and the corresponding epoxide was achieved with excellent yields and selectivity. In addition, the effect of axial ligand was studied on the epoxidation reaction and pyridine $N$-oxide (PNO) was chosen as an excellent axial ligand in dichloromethane. Furthermore, the heterogeneous catalyst showed good stability and the magnetic properties (which made possible the easy recovery of catalyst with external magnet) without significant decrease in the activity in the epoxidation reaction.
\end{abstract}

Keywords. $\mathrm{Co}$ (III) salen complex; $\mathrm{Fe}_{3} \mathrm{O}_{4} / \mathrm{SiO}_{2}$; Olefins; epoxidation; m-chloroperbenzoic acid.

\section{Introduction}

Epoxidation of terminal alkenes to the corresponding epoxides is especially interesting because epoxides are valuable intermediates for the synthesis of fine chemicals, pharmaceuticals and agrochemicals. ${ }^{1,2}$ Schiff bases and their stable complexes with most of transition metals have a key role in coordination chemistry. ${ }^{3-6}$ They can be prepared simply and cheaply for industrial applications. A number of homogeneous and heterogeneous Schiff base complexes were developed for the oxidation reactions and, in particular, epoxidation of alkenes. Although, great attention was shown to the epoxidation of alkenes using $\mathrm{Mn}(\mathrm{III})$ salen complex, ${ }^{7-14}$ several investigations have reported that $\mathrm{Co}$ (III) complexes are good catalysts for the epoxidation of alkenes. ${ }^{15-18}$ Covalent attachment of Co(III) complexes on a solid support such as polymer, zeolite and silica have recently been reported as innovation in the catalytic properties of such compounds. ${ }^{19-23}$

Recently, magnetic nanoparticles with special properties, such as ease of separation by external magnet,

*For correspondence high catalyst loading capacity due to high surface area, high dispersion, convenient recycling of catalyst and outstanding stability, have been extensively employed as a good candidate for catalyst supports. ${ }^{24,25}$ In addition, they possess attractive properties (low toxicity and high biocompatibility, super paramagnetism, high magnetic susceptibility and saturation magnetization) that could potentially be used in catalysis, magnetic resonance imaging contrast enhancement, drug delivery, data storage, magnetic bioseparation, gene manipulation, targeted drug carrier, enzyme immobilization, immunoassay and environmental remediation. ${ }^{26-33}$ However, pure magnetic particles such as $\mathrm{Fe}_{3} \mathrm{O}_{4}$ NPs usually suffer from a large aggregation which alters magnetic properties. To overcome this problem, an appropriate coating material such as silica was applied to avoid such limitations. ${ }^{34}$ Several types of functionalized $\mathrm{Fe}_{3} \mathrm{O}_{4}$ NPs and studies on immobilization of organo-catalysts and metal on silica-coated $\mathrm{Fe}_{3} \mathrm{O}_{4} \mathrm{NPs}$ have also been recently reported. ${ }^{26,35-37}$ In continuation of the study of metal salen complexs, ${ }^{38,39}$ herein, we synthesized $\mathrm{Co}$ (III) salen complex anchored onto the $\mathrm{Fe}_{3} \mathrm{O}_{4} / \mathrm{SiO}_{2} \mathrm{NPs}\left(\mathrm{Co} @ \mathrm{Fe}_{3} \mathrm{O}_{4} / \mathrm{SiO}_{2}\right)$. The heterogeneous catalyst was used in the epoxidation of alkenes using $m$-chloroperbenzoic acid ( $m$-CPBA) as an oxidant in dichloromethane (Scheme 1). 


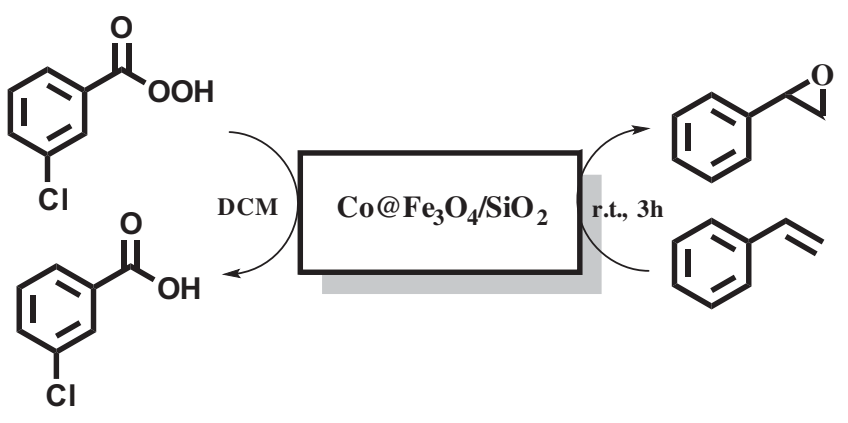

Scheme 1. Schematic illustration for the epoxidation of alkenes.

\section{Experimental}

\subsection{Materials}

Tetraethoxysilane (TEOS), $\mathrm{FeCl}_{3} \cdot 6 \mathrm{H}_{2} \mathrm{O}, \mathrm{FeCl}_{2} \cdot 4 \mathrm{H}_{2} \mathrm{O}$, styrene, $\alpha$-methylstyrene, 4-chlorostyrene, cyclooctene, indene, cis $\&$ trans stilbene, cyclohexene, 1 -octene, pyridine $N$-oxide (PNO), pyridine (Py), $N$-methylmorpholine $N$-oxide (NMNO), 1-methyl imidazole (MI), imidazole (IM), ethylacetate (EtOAc), dichloromethane (DCM), $\mathrm{CH}_{3} \mathrm{CN}$, toluene, $\mathrm{CHCl}_{3}$, ethanol (EtOH), tetrahydrofuran (THF), m-chloroperbenzoic acid ( $m$-CPBA), $\mathrm{NaIO}_{4}, \mathrm{NH}_{4} \mathrm{OAc}$, tert-butylhydrogenperoxide (TBHP), $\mathrm{PhI}(\mathrm{OAc})_{2}, \mathrm{H}_{2} \mathrm{O}_{2}$ (30\%), (R,R)-1,2-cyclohexanediamine, 2,4-dihydroxybenzaldehyde and oxone were purchased from Merck Company and used without purification.

The IR spectra were recorded on a Perkin-Elmer 783 Infrared spectrophotometer in a $\mathrm{KBr}$ pellet, scanning from 4000 to $600 \mathrm{~cm}^{-1}$ at room temperature. The XRD measurements were recorded using a Bruker $\mathrm{D}_{8}$-advance $\mathrm{X}$ ray diffractometer with $\mathrm{Cu} \mathrm{K}_{\alpha}$ radiation $(\mathrm{k}=1.5406 \AA)$. The TEM images were obtained using the Philips CM10 instrument. Magnetization measurements were carried out at $300 \mathrm{~K}$ on a vibrating sample magnetometer (VSM Leak shore 7200). TGA curves were obtained using a Perkin-Elmer Diamond TG/DTA thermal analyzer by heating the samples in an Argon flow at a rate of $100 \mathrm{~mL} \mathrm{~min}^{-1}$ with a heating rate of $10^{\circ} \mathrm{C} \mathrm{min}-1$. The yields and selectivity of the products were obtained by GC-17A Shimadzu with capillary column (Shimadzu, CBP5, $30 \mathrm{~m} \times 25 \mathrm{~mm} \times 0.25 \mu \mathrm{m}$ ).

\subsection{Synthesis of $\mathrm{Fe}_{3} \mathrm{O}_{4} / \mathrm{SiO}_{2}$ nanocatalyst}

Black powder of magnetic $\mathrm{Fe}_{3} \mathrm{O}_{4}$ NPs was synthesized as described in the literature. ${ }^{40}$ The $\mathrm{Fe}_{3} \mathrm{O}_{4} / \mathrm{SiO}_{2}$ NPs were synthesized by the Stober method with some modification. ${ }^{41}$ Briefly, $0.5 \mathrm{~g}$ of $\mathrm{Fe}_{3} \mathrm{O}_{4}(2.1 \mathrm{mmol})$ was dispersed in the solution containing the mixture of ethanol/deionized water (80:20 mL), followed by the addition of $3 \mathrm{~mL}$ of $\mathrm{NH}_{3}$. Then, $1.5 \mathrm{~mL}$ of TEOS was added dropwise to the mixture and stirred mechanically for $20 \mathrm{~h}$ at room temperature. The coreshell $\mathrm{Fe}_{3} \mathrm{O}_{4} / \mathrm{SiO}_{2}$ was separated by an external magnet, washed with deionized water and ethanol three times and dried at $80^{\circ} \mathrm{C}$ for $8 \mathrm{~h} . \mathrm{Fe}_{3} \mathrm{O}_{4}: \mathrm{IR} / \mathrm{cm}^{-1}: 3446,580$; XRD:
$2 \theta=30.2^{\circ}, 35.4^{\circ}, 43.3^{\circ}, 53.6^{\circ}, 57.5^{\circ}, 63.1^{\circ} . \mathrm{Fe}_{3} \mathrm{O}_{4} / \mathrm{SiO}_{2}$ : $\mathrm{IR} / \mathrm{cm}^{-1}: 3446,1059,954,755,580$; XRD: $2 \theta=15-27^{\circ}$, $30.2^{\circ}, 35.4^{\circ}, 43.3^{\circ}, 53.6^{\circ}, 57.5^{\circ}, 63.1^{\circ}$.

\subsection{Synthesis of ligand salen}

N,N'-Bis(2,4-di-hydroxybenzaldehyde)-1,2-cyclohexanediamine was synthesized as described in the literature. ${ }^{42} \mathrm{~N}, \mathrm{~N}$ '-Bis (2,4-di-hydroxybenzaldehyde)-1,2-cyclohexanediamine: Light brown Solid, yield $85 \%$, M.p. $=187-189^{\circ} \mathrm{C}, \mathrm{IR} / \mathrm{cm}^{-1}$ : 2600-3450(br, OH), 2920(CH2), 2880(CH2), 1615(vs, $\mathrm{C}=\mathrm{N}), 1496(\mathrm{~s}), 1425(\mathrm{~s}), 1380(\mathrm{vs}), 1247(\mathrm{~m}), 1170(\mathrm{~s}, \mathrm{C}-$ O), 970(s), 925(m), 835(s), 780(m), 730(vs). ${ }^{1} \mathrm{H}-\mathrm{NMR}$ (DMSO, $250 \mathrm{MHz}$ ) ppm :1.5 (4H, CH2), 1.8 (4H, CH2), 3.1 $(2 \mathrm{H}, \mathrm{CH}), 6.37-7.43(\mathrm{C}, 6 \mathrm{H}, \mathrm{CHarom}), 8.43(\mathrm{~s}, 1 \mathrm{H}$, $\mathrm{CH}=\mathrm{N}), 8.50(\mathrm{~s}, 1 \mathrm{H}, \mathrm{CH}=\mathrm{N}), 9.8-10.20(\mathrm{br}, 2 \mathrm{H}, \mathrm{OH})$, $12.72(\mathrm{~s}, 1 \mathrm{H}, \mathrm{OH}), 13.16(\mathrm{~s}, 1 \mathrm{H}, \mathrm{OH}) ;{ }^{13} \mathrm{C}-\mathrm{NMR}(\mathrm{DMSO}$, $62.7 \mathrm{MHz}$ ) ppm: 23.6, 29.2, 71.8, 104.5, 109.2, 118.1, 133.0, 161.0, 162.5, 163.1; Ms, m/z (\%), 355.16( $\mathrm{M}^{+}+1$, 2), 354.16(M+, 20), 277(10), 262(38), 227(41), 183(39), 122(base peak), 109(29), 77(55).

\subsection{Synthesis of Co(III) salen complex}

$\mathrm{Co}(\mathrm{III})$ salen complex was synthesized as described in the literature. ${ }^{43} \mathrm{Co}(\mathrm{III})$ salen complex: Dark brown Solid, yield 90\%, IR/ $\left./ \mathrm{cm}^{-1}\right), 2600-3450(\mathrm{br}, \mathrm{OH}), 2920(\mathrm{CH} 2)$, 2880(CH2), 1590(vs, C=N), 1496(s), 1425(s), 1380(vs), 1247(m), 1170(s, C-O), 970(s), 925(m), 835(s), 780(m), 730 (vs).

\subsection{Synthesis of $\mathrm{Co} @ \mathrm{Fe}_{3} \mathrm{O}_{4} / \mathrm{SiO}_{2}$ nanocatalyst}

Homogeneous Co(III) salen complex was chemically immobilized onto the $\mathrm{Fe}_{3} \mathrm{O}_{4} / \mathrm{SiO}_{2}$. In brief, $2 \mathrm{~g}$ of $\mathrm{Fe}_{3} \mathrm{O}_{4} / \mathrm{SiO}_{2}$ was dispersed in $100 \mathrm{~mL}$ of dry toluene under magnetic stirring followed by the addition of $0.5 \mathrm{~g}$ of homogeneous Co(III) complex (Scheme 1) and refluxed for $24 \mathrm{~h}$ under inert atmosphere. After the completion of the reaction, the heterogeneous catalyst $\left(\mathrm{Co} @ \mathrm{Fe}_{3} \mathrm{O}_{4} / \mathrm{SiO}_{2}\right.$ ) was washed in turn with dry toluene, EtOH and extracted repeatedly on a Soxhlet extractor with methanol and dichloromethane until the washing became colorless. The heterogeneous catalyst was dried at $70^{\circ} \mathrm{C}$ under vacuum for $6 \mathrm{~h}$. The $\mathrm{Co} @ \mathrm{Fe}_{3} \mathrm{O}_{4} / \mathrm{SiO}_{2}$ was characterized by FT-IR, TEM, XRD, VSM, BET and TGA.

\subsection{General procedure for the epoxidation of alkenes}

Typically, $2.5 \mathrm{~mol} \%$ of $\mathrm{Co} @ \mathrm{Fe}_{3} \mathrm{O}_{4} / \mathrm{SiO}_{2}$ as catalyst (based on Co element) was dispersed in dichloromethane $(3 \mathrm{~mL})$ for $20 \mathrm{~min}$. Styrene $(1 \mathrm{mmol})$, toluene (internal standard, $40 \mu \mathrm{L}), m$-CPBA $(2 \mathrm{mmol})$ as oxidant and PNO $(0.5 \mathrm{mmol})$ as additive were added to the mixture. The reaction mixture was stirred at room temperature for appropriate times and the progress of the reaction was monitored by TLC. 
After the completion of the reaction, the catalyst was separated using external magnet and the solution was washed with $\mathrm{NaOH}(1 \mathrm{M}, 8 \mathrm{~mL})$ and brine $(8 \mathrm{~mL})$ and dried over $\mathrm{MgSO}_{4}$. Finally, the solution was concentrated to $1 \mathrm{~mL}$ and the yield and selectivity of products were determined by GC. The heterogeneous catalyst was washed with ethanol and reused.

\section{Results and Discussion}

$\mathrm{Co} @ \mathrm{Fe}_{3} \mathrm{O}_{4} / \mathrm{SiO}_{2} \mathrm{NPs}$ was synthesized according to the procedure illustrated in Scheme 2. Initially, $\mathrm{Fe}_{3} \mathrm{O}_{4} \mathrm{NPs}$ was synthesized and coated with silica $\left(\mathrm{Fe}_{3} \mathrm{O}_{4} / \mathrm{SiO}_{2}\right)$. The homogeneous $\mathrm{Co}$ (III) salen complex was immobilized onto the $\mathrm{Fe}_{3} \mathrm{O}_{4} / \mathrm{SiO}_{2}$ NPs afforded the desired $\mathrm{Co} @ \mathrm{Fe}_{3} \mathrm{O}_{4} / \mathrm{SiO}_{2}$ nanoparticle.

\subsection{Characterizations of the catalyst}

The magnetic properties of the $\mathrm{Fe}_{3} \mathrm{O}_{4}, \mathrm{Fe}_{3} \mathrm{O}_{4} / \mathrm{SiO}_{2}$ and $\mathrm{Co} @ \mathrm{Fe}_{3} \mathrm{O}_{4} / \mathrm{SiO}_{2}$ NPs were investigated by different techniques (FT-IR, TEM, VSM, XRD, BET, AAS and TGA). The IR spectrum of $\mathrm{Fe}_{3} \mathrm{O}_{4}$ NPs shows important vibration bands in $560-590$ and $3400 \mathrm{~cm}^{-1}$ which are due to $\mathrm{Fe}-\mathrm{O}$ and $\mathrm{O}-\mathrm{H}$, respectively (not listed). Salen ligand shows important band at $3450 \mathrm{~cm}^{-1}$ which belongs to the $\mathrm{O}-\mathrm{H}$ group (Figure 1a). Also, the bands at 2920 and $2880 \mathrm{~cm}^{-1}$ are assigned to the aliphatic $\mathrm{CH}$ bond. Furthermore, the band at $1615 \mathrm{~cm}^{-1}$ corresponds to the $\mathrm{C}=\mathrm{N}$ bond. This band shifts to the lower position $\left(25 \mathrm{~cm}^{-1}\right)$ in homogeneous $\mathrm{Co}$ (III) salen complex, which suggests the coordination of Co through $\mathrm{C}=\mathrm{N}$ bond (Figure 1b). In Figure 1(d) which belongs to the $\mathrm{Fe}_{3} \mathrm{O}_{4} / \mathrm{SiO}_{2} \mathrm{NPs}$, several important vibration bands at $560-590,954$, and $3400 \mathrm{~cm}^{-1}$ are observed.
These vibration bands are due to $\mathrm{Fe}-\mathrm{O}, \mathrm{Si}-\mathrm{OH}$, and $\mathrm{O}-$ $\mathrm{H}$, respectively. Also, the vibration bands at 755 and $1100 \mathrm{~cm}^{-1}$ are due to $\mathrm{Si}-\mathrm{O}-\mathrm{Si}$. The vibration bands at 755,954 and $1100 \mathrm{~cm}^{-1}$ confirmed that the silica shell was coated on the surface of the $\mathrm{Fe}_{3} \mathrm{O}_{4}$ NPs. The IR spectra of $\mathrm{Co} @ \mathrm{Fe}_{3} \mathrm{O}_{4} / \mathrm{SiO}_{2} \mathrm{NPs}$ showed a strong vibration band at $1595 \mathrm{~cm}^{-1}$. This vibration band is assigned coordination to $\mathrm{Co}$ through $\mathrm{C}=\mathrm{N}$ functional groups (Figure 1c). Furthermore, new stretching, vibration bands at 1590, 2880 and $2920 \mathrm{~cm}^{-1}$ confirmed the immobilization of homogeneous Co(III) salen complex on the $\mathrm{Fe}_{3} \mathrm{O}_{4} / \mathrm{SiO}_{2} \mathrm{NPs}$ (Figure 1c).

The TGA curves of $\mathrm{Fe}_{3} \mathrm{O}_{4} / \mathrm{SiO}_{2}$ and $\mathrm{Co} @ \mathrm{Fe}_{3} \mathrm{O}_{4} / \mathrm{SiO}_{2}$ NPs are shown in Figure 2. In the TG cure of $\mathrm{Fe}_{3} \mathrm{O}_{4} / \mathrm{SiO}_{2}$ NPs, a weight loss over the range of 90 $165^{\circ} \mathrm{C}$ was observed (3\%). This weight loss is attributed to the loss of adsorbed water and dehydroxylation of

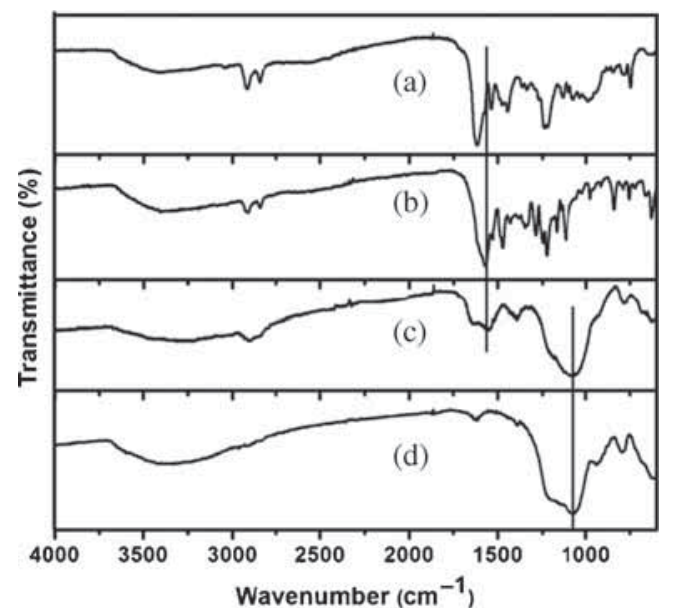

Figure 1. FT-IR spectra. (a) salen, (b) Co complex, (c) $\mathrm{Co} @ \mathrm{Fe}_{3} \mathrm{O}_{4} / \mathrm{SiO}_{2}$, and (d) $\mathrm{Fe}_{3} \mathrm{O}_{4} / \mathrm{SiO}_{2}$ NPs.
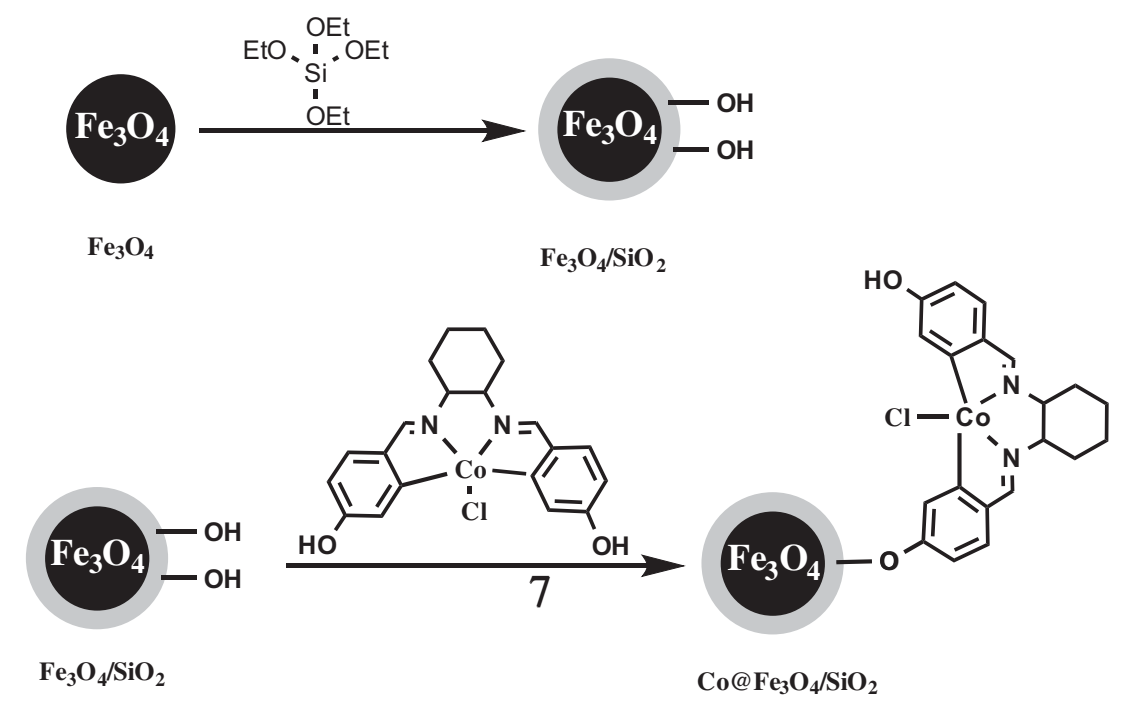

Scheme 2. Schematic illustration for the preparation of $\mathrm{Co} @ \mathrm{Fe}_{3} \mathrm{O}_{4} / \mathrm{SiO}_{2}$ catalyst. 
internal ${ }^{-} \mathrm{OH}$ groups. The second weight loss over the range $250-590^{\circ} \mathrm{C}$ wa observed. This weight loss is ascribed to even further decomposition of the material. The total weight losses were approximately $10 \%$ (Figure 2a). As shown in Figure 2b, the first step of weight loss is decreased after the immobilization of $\mathrm{Co}$ (III) salen complex onto the $\mathrm{Fe}_{3} \mathrm{O}_{4} / \mathrm{SiO}_{2}$ NPs which indicated that the $\mathrm{Co}$ (III) salen complex has been successfully immobilized onto the $\mathrm{Fe}_{3} \mathrm{O}_{4} / \mathrm{SiO}_{2}$. The TGA curve of $\mathrm{Co} @ \mathrm{Fe}_{3} \mathrm{O}_{4} / \mathrm{SiO}_{2}$ has two weight losses over the range of $90-160^{\circ} \mathrm{C}$ and $250-650^{\circ} \mathrm{C}$ which are similar to the $\mathrm{Fe}_{3} \mathrm{O}_{4} / \mathrm{SiO}_{2}$. The total weight losses were approximately $13 \%$ (Figure $2 \mathrm{~b}$ ). The loading of $\mathrm{Co}$ (III) salen complex is $0.40 \mathrm{mmol} \mathrm{g}^{-1}$ based on the difference in the weight losses for $\mathrm{Fe}_{3} \mathrm{O}_{4} / \mathrm{SiO}_{2}$ and $\mathrm{Co} @ \mathrm{Fe}_{3} \mathrm{O}_{4} / \mathrm{SiO}_{2}$.

The vibrating sample magnetometer (VSM) recordings of $\mathrm{Fe}_{3} \mathrm{O}_{4}, \mathrm{Fe}_{3} \mathrm{O}_{4} / \mathrm{SiO}_{2} \mathrm{NPs}$ and $\mathrm{Co} @ \mathrm{Fe}_{3} \mathrm{O}_{4} / \mathrm{SiO}_{2}$ are shown in Figure 3. As obvious in Figure 3, all the nanoparticles have superparamagnetism property at $300 \mathrm{~K}$ and no hysteresis phenomenon was observed. The values of saturation magnetization for $\mathrm{Fe}_{3} \mathrm{O}_{4}$, $\mathrm{Fe}_{3} \mathrm{O}_{4} / \mathrm{SiO}_{2}$ and $\mathrm{Co} @ \mathrm{Fe}_{3} \mathrm{O}_{4} / \mathrm{SiO}_{2}$ NPs catalyst are

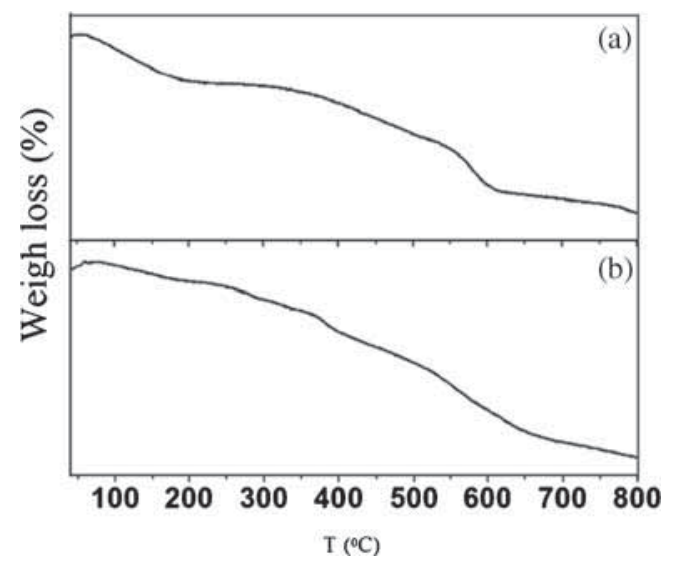

Figure 2. Thermogravimetric weight loss pattern of (a) $\mathrm{Fe}_{3} \mathrm{O}_{4} / \mathrm{SiO}_{2} \mathrm{NPs}$ and (b) $\mathrm{Co} @ \mathrm{Fe}_{3} \mathrm{O}_{4} / \mathrm{SiO}_{2}$ with temperature raised of $10^{\circ} \mathrm{C} / \mathrm{min}$.

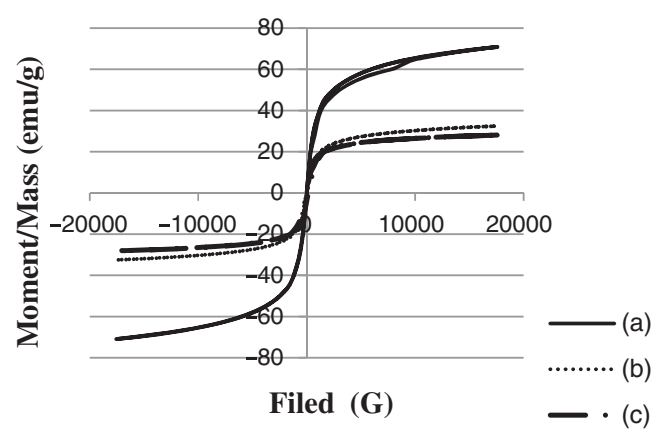

Figure 3. Magnetization curves of (a) $\mathrm{Fe}_{3} \mathrm{O}_{4}$, (b) $\mathrm{Fe}_{3} \mathrm{O}_{4} /$ $\mathrm{SiO}_{2} \mathrm{NPs}$, (c) $\mathrm{Co} @ \mathrm{Fe}_{3} \mathrm{O}_{4} / \mathrm{SiO}_{2} \mathrm{NPs}$ at $300 \mathrm{~K}$.
$70.495,38.30$ and $34.30 \mathrm{emu} / \mathrm{g}$, respectively. By immo bilization of $\mathrm{SiO}_{2}$ and $\mathrm{Co}$ (III) salen complex onto $\mathrm{Fe}_{3} \mathrm{O}_{4}$, the saturation magnetization values of $\mathrm{Fe}_{3} \mathrm{O}_{4} /$ $\mathrm{SiO}_{2}$ and $\mathrm{Co} @ \mathrm{Fe}_{3} \mathrm{O}_{4} / \mathrm{SiO}_{2}$ catalyst were decreased. Despite the considerable decrease in the magnetization of $\mathrm{Co} @ \mathrm{Fe}_{3} \mathrm{O}_{4} / \mathrm{SiO}_{2}$, this heterogeneous catalyst can still be separated from the solution by using an external magnetic field on the side wall of the reactor.

Figure 4 shows the XRD patterns of $\mathrm{Fe}_{3} \mathrm{O}_{4}, \mathrm{Fe}_{3} \mathrm{O}_{4} /$ $\mathrm{SiO}_{2}$ and $\mathrm{Co} @ \mathrm{Fe}_{3} \mathrm{O}_{4} / \mathrm{SiO}_{2}$ NPs which were determined by powder X-ray diffraction (XRD). The XRD pattern of $\mathrm{Fe}_{3} \mathrm{O}_{4}$ NPs (Figure 4A) indicates a crystalline structure at $2 \theta: 30.2^{\circ}, 35.4^{\circ}, 43.3^{\circ}, 53.6^{\circ}, 57.5^{\circ}$ and $63.1^{\circ}$ which are assigned to the (2 20$),\left(\begin{array}{lll}3 & 1 & 1\end{array}\right),\left(\begin{array}{lll}4 & 0 & 0\end{array}\right)$, (4 22 2), ( $\left(\begin{array}{lll}5 & 1 & 1\end{array}\right)$ and (4 40 ) crystallographic faces of magnetite. A broad peak at $2 \theta=15-27^{\circ}$ in the XRD patterns of $\mathrm{Fe}_{3} \mathrm{O}_{4} / \mathrm{SiO}_{2}$ and $\mathrm{Co} @ \mathrm{Fe}_{3} \mathrm{O}_{4} / \mathrm{SiO}_{2}$ NPs are assigned to amorphous silica Figure 4(B, C). Using Debye-Scherrer equation (1), the size of these particles could be estimated by determining the width of the (3 1 1) Bragg reflection (1).

$$
D=\frac{\mathrm{k} \lambda}{\beta \cos \theta}
$$

where, $\lambda$ is the wavelength of the $\mathrm{X}$-ray, $\mathrm{k}$ is the Scherrer constant, $\beta$ is the half-width of the peak and $\theta$ is half of the Bragg angle. Therefore, the size (D) of the particles could be estimated. The average diameter of $\mathrm{Fe}_{3} \mathrm{O}_{4}$ NPs was $15 \mathrm{~nm}$, while the diameter of $\mathrm{Fe}_{3} \mathrm{O}_{4} / \mathrm{SiO}_{2} \mathrm{NPs}$ was about $20 \mathrm{~nm}$ which is due to the agglomeration of $\mathrm{Fe}_{3} \mathrm{O}_{4}$ inside nanosphere and surface growth of silica on the shell.

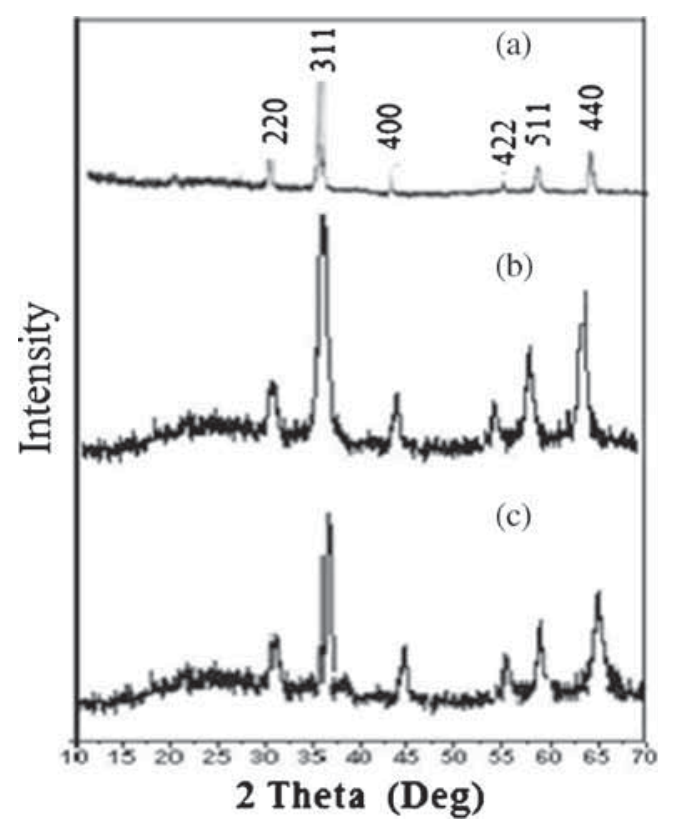

Figure 4. $\mathrm{XRD}$ pattern of (A) $\mathrm{Fe}_{3} \mathrm{O}_{4}$, (B) $\mathrm{Fe}_{3} \mathrm{O}_{4} / \mathrm{SiO}_{2} \mathrm{NPs}$ and $(\mathrm{C}) \mathrm{Co} @ \mathrm{Fe}_{3} \mathrm{O}_{4} / \mathrm{SiO}_{2} \mathrm{NPs}$. 


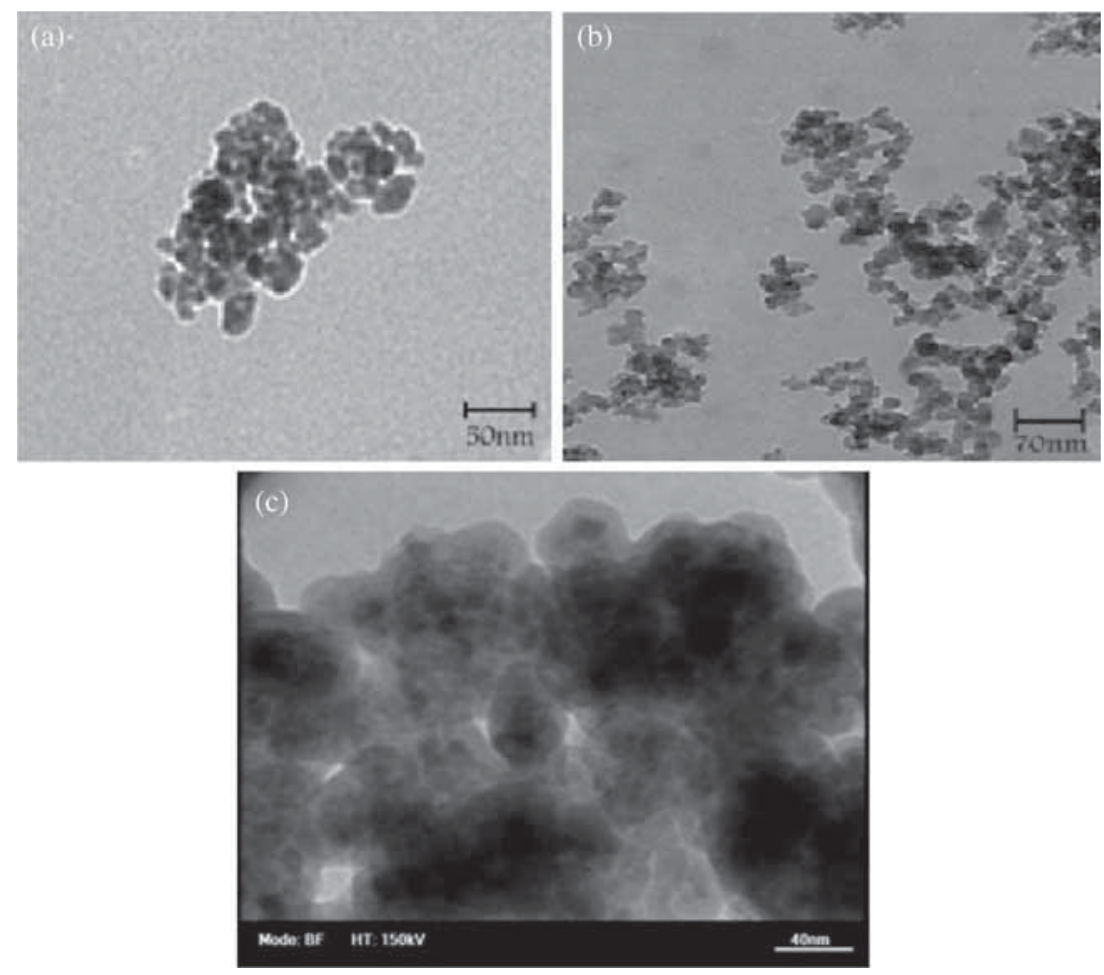

Figure 5. TEM images of (a) $\mathrm{Fe}_{3} \mathrm{O}_{4}$, (b) $\mathrm{Fe}_{3} \mathrm{O}_{4} / \mathrm{SiO}_{2}$ and (c) $\mathrm{Co} @ \mathrm{Fe}_{3} \mathrm{O}_{4} / \mathrm{SiO}_{2}$.

Figures $5 \mathrm{a}$ and $5 \mathrm{~b}$ show the TEM images of $\mathrm{Fe}_{3} \mathrm{O}_{4}$ and $\mathrm{Fe}_{3} \mathrm{O}_{4} / \mathrm{SiO}_{2}$ NPs. Considering the TEM of $\mathrm{Fe}_{3} \mathrm{O}_{4}$ and $\mathrm{Fe}_{3} \mathrm{O}_{4} / \mathrm{SiO}_{2}$, the average size of 16 and $21 \mathrm{~nm}$ were obtained which are similar to the results of XRD patterns. The TEM images of $\mathrm{Fe}_{3} \mathrm{O}_{4} / \mathrm{SiO}_{2}$ NPs indicated the successful coating of silica shell on the magnetic $\mathrm{Fe}_{3} \mathrm{O}_{4}$ NPs (Figure 5b).

The TEM image of $\mathrm{Co} @ \mathrm{Fe}_{3} \mathrm{O}_{4} / \mathrm{SiO}_{2}$ showed the successful immobilization of $\mathrm{Co}$ (III) salen complex on the $\mathrm{Fe}_{3} \mathrm{O}_{4} / \mathrm{SiO}_{2}$ NPs (Figure 5c). The BET specific surface area of the $\mathrm{Co} @ \mathrm{Fe}_{3} \mathrm{O}_{4} / \mathrm{SiO}_{2}$ was measured at room temperature by nitrogen physisorption and the surface area of was found to be $20 \mathrm{~m}^{2} / \mathrm{g}$. The loading of $\mathrm{Co}$ (III) salen complex on the $\mathrm{Fe}_{3} \mathrm{O}_{4} / \mathrm{SiO}_{2}$ was $0.42 \mathrm{mmol} / \mathrm{g}$ based on Co elemental analysis by AAS.

\subsection{Catalytic activity studies}

3.2a Epoxidation of unfunctionalized alkenes: The catalytic activity of $\mathrm{Co} @ \mathrm{Fe}_{3} \mathrm{O}_{4} / \mathrm{SiO}_{2}$ was studied for the epoxidaton of terminal alkenes. The activity and selectivity of $\mathrm{Co} @ \mathrm{Fe}_{3} \mathrm{O}_{4} / \mathrm{SiO}_{2}$ was compared with the respective homogeneous Co salen complex. Initially, the reaction of styrene as the test reaction was investigated using $m$-CPBA as the oxidant and PNO as axial ligand at room temperature in dichloromethane (DCM) as solvent. In search of optimal reaction conditions to achieve maximum selectivity and yield of styrene oxide, the effects of different amounts of catalyst, oxidant, axial ligand, solvent, temperature and time were investigated for the test reaction.

3.2b The effect of catalyst amount on the epoxidation of styrene catalyzed by $\mathrm{Co} @ \mathrm{Fe}_{3} \mathrm{O}_{4} / \mathrm{SiO}_{2}$ : To optimize the amount of catalyst, different amounts of $\mathrm{Co} @ \mathrm{Fe}_{3} \mathrm{O}_{4} / \mathrm{SiO}_{2}(0.5-3 \mathrm{~mol} \%$ based on Co element) were studied in the epoxidation of styrene ( $1 \mathrm{mmol})$ with $m$-CPBA $(2 \mathrm{mmol})$ at room temperature in $3 \mathrm{~mL} \mathrm{DCM}$ and the results showed that $2.5 \mathrm{~mol} \%$ of $\mathrm{Co} @ \mathrm{Fe}_{3} \mathrm{O}_{4} / \mathrm{SiO}_{2}$ is the optimum amount of catalyst (Table 1, entry 5). The epoxidation reaction of styrene was carried out over parent of $\mathrm{Co} @ \mathrm{Fe}_{3} \mathrm{O}_{4} / \mathrm{SiO}_{2}$ $\left(\mathrm{Fe}_{3} \mathrm{O}_{4}\right.$ and $\left.\mathrm{Fe}_{3} \mathrm{O}_{4} / \mathrm{SiO}_{2}\right)$ to determine which part of the $\mathrm{Co} @ \mathrm{Fe}_{3} \mathrm{O}_{4} / \mathrm{SiO}_{2}$ has catalytic activity and the results showed that low yields were observed (20 and 42\%, respectively) (not listed). In the absence of catalyst, since there are no active sites, negligible conversion was found which demonstrates that the epoxidation reaction is a catalytic process (Table 1, entry 8 ). The effect of axial ligand (PNO) was also investigated and the results showed that in the absence of PNO an obvious decrease in the yield (70\%) was observed (not listed). Also, in the homogeneous phases, the $\mathrm{Co}$ (III) complex was used under the same reaction conditions and the time of reaction is shortened to $2 \mathrm{~h}$ (Table 1 , entry 8 ). 
3.2c The effect of different solvents and time on the epoxidation of styrene catalyzed by $\mathrm{Co} @ \mathrm{Fe}_{3} \mathrm{O}_{4} / \mathrm{SiO}_{2}$ : The selected solvents should be stable and dissolve the substrate and oxidant. So, different types of solvent with a range of polarity were investigated in the reaction under the same conditions. Considering the results, the polarity of solvents was effective on the catalytic activity of $\mathrm{Co} @ \mathrm{Fe}_{3} \mathrm{O}_{4} / \mathrm{SiO}_{2}$ (Table 2). Under the mentioned conditions, the reaction did not proceed well in water which can be due to the low dispersion of the catalyst and collision with the substrate (Table 2, entry 1). ${ }^{44}$ In the case of ethanol and methanol, the low yiled of styrene oxide was observed which may be because of the coordination of solvent with Co(III) ions and competing with the oxidation reaction. ${ }^{45,46}$ Furthermore, poor conversion of styrene oxide was observed in the nonpolar media (Table 2, entry 5). Finally, the excellent yield of the styrene oxide was observed in DCM (Table 2, entry 9).

Table 1. Optimization of different amount of $\mathrm{Co} @ \mathrm{Fe}_{3} \mathrm{O}_{4} /$ $\mathrm{SiO}_{2}$ nanocatalyst on the reaction of styrene with $m$-CPBA as a model reaction. ${ }^{\text {a }}$

\begin{tabular}{lcc}
\hline Entry & Catalyst amount $(\mathrm{mol} \%)$ & Yield $^{\mathrm{b}}(\%)$ \\
\hline 1 & 0.5 & 20 \\
2 & 1.0 & 41 \\
3 & 1.5 & 64 \\
4 & 2.0 & 80 \\
5 & 2.5 & 95 \\
6 & 3.0 & 97 \\
7 & homogeneous Co (III) complex $(2.5 \mathrm{~mol} \%)$ & 98 \\
8 & - & 0 \\
\hline
\end{tabular}

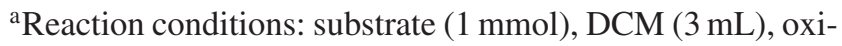
dant (2 mmol) and $\mathrm{Co} @ \mathrm{Fe}_{3} \mathrm{O}_{4} / \mathrm{SiO}_{2}(2.5 \mathrm{~mol} \%$ based on Co) at r.t. Duration: 3 h. ${ }^{\mathrm{b}}$ Determined by GC with a Shimadzu CBP5 column $(30 \mathrm{~m} \times 0.32 \mathrm{~mm} \times 0.25 \mathrm{~mm})$.

Table 2. The effect of different solvents on the epoxidation of styrene. ${ }^{\mathrm{a}}$

\begin{tabular}{lcc}
\hline Entry & Solvent & Yield $^{\mathrm{b}}(\%)$ \\
\hline 1 & $\mathrm{H}_{2} \mathrm{O}$ & 13 \\
2 & $\mathrm{EtOH}: \mathrm{H}_{2} \mathrm{O}$ & 22 \\
3 & $\mathrm{MeOH}$ & 28 \\
4 & $\mathrm{EtOH}$ & 30 \\
5 & $\mathrm{THF}$ & 40 \\
6 & $\mathrm{CHCl}_{3}$ & 50 \\
7 & $\mathrm{CH}_{3} \mathrm{CN}$ & 65 \\
8 & $\mathrm{EtOAc}^{2}$ & 80 \\
9 & $\mathrm{DCM}$ & 95 \\
\hline
\end{tabular}

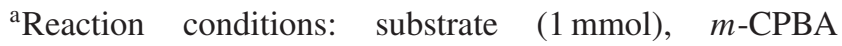
( $2 \mathrm{mmol})$ and $\mathrm{Co} @ \mathrm{Fe}_{3} \mathrm{O}_{4} / \mathrm{SiO}_{2}(2.5 \mathrm{~mol} \%$ based on Co element) at r.t. duration: $3 \mathrm{~h}$. ${ }^{\mathrm{b}}$ Determined by GC with a Shimadzu CBP5 column $(30 \mathrm{~m} \times 0.32 \mathrm{~mm} \times 0.25 \mathrm{~mm})$.
The progress of the conversion of styrene was also investigated at different times (Figure 6). As shown in the Figure 6, the conversion increased linearly with the reaction time and reached up to $70 \%$ at $2 \mathrm{~h}$. Increasing the time of reaction to $3 \mathrm{~h}$ gradually increased the yield of styrene oxide to $95 \%$ with constant selectivity of $99 \%$.

\section{2d The effect of different oxidants/additives in the} epoxidation of styrene: $\mathrm{Co}(\mathrm{III})$ is a good Lewis acid, which makes it able to withdraw electron from the peroxidic oxygen and susceptible to be attacked by nucleophilic alkene in DCM medium. The conversion and selectivity of the reaction were investigated in the presence of various oxidants ( $m$-CPBA, urea hydrogen peroxide (UHP), $\mathrm{NaIO}_{4}$, Oxone, $\mathrm{H}_{2} \mathrm{O}_{2}, \mathrm{PhI}(\mathrm{OAc})_{2}, \mathrm{PhIO}$ and TBHP). As can be seen from Table 3 , in the absence of oxidant, no yield was observed (Table 3, entry 1). In the presence of some oxidants, such as UHP, $\mathrm{H}_{2} \mathrm{O}_{2}$, $\mathrm{PhIO}, \mathrm{PhI}(\mathrm{OAc})_{2}$, low yield of products was observed (Table 3, entries 2-5). Oxone and $\mathrm{NaIO}_{4}$ (for both of them, the 2:1 mixture of acetonitrile: water was used as the solvent) gave better yields (Table 3, entries 6, $7)$. The best yields were observed in the presence of $m$-CPBA (Table 3, entry 9). Different amount of the oxidant was also tested and the best result was obtained

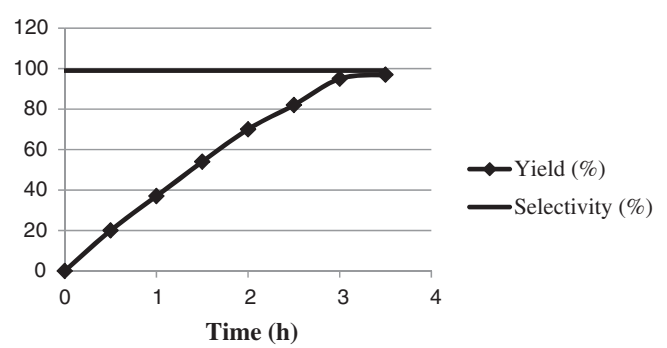

Figure 6. Change of conversion with reaction time for the model reaction catalyzed by fresh $\mathrm{Co} @ \mathrm{Fe}_{3} \mathrm{O}_{4} / \mathrm{SiO}_{2}$ catalyst.

Table 3. The effect of different oxidants on the epoxidation of styrene catalyzed by $\mathrm{Co} @ \mathrm{Fe}_{3} \mathrm{O}_{4} / \mathrm{SiO}_{2}$. ${ }^{\mathrm{a}}$

\begin{tabular}{lcc}
\hline Entry & Oxidant & Yield (\%) \\
\hline 1 & - & 0 \\
2 & $\mathrm{H}_{2} \mathrm{O}_{2}$ & 25 \\
3 & $\mathrm{PhIO}$ & 27 \\
4 & $\mathrm{PhI}(\mathrm{OAc})_{2}$ & 22 \\
5 & $\mathrm{UHP}_{2}$ & 30 \\
6 & $\mathrm{NaIO}_{4}$ & 50 \\
7 & Oxone & 60 \\
8 & TBHP & 85 \\
9 & $m$-CPBA & 95 \\
\hline
\end{tabular}

a Reaction conditions: Styrene ( $1 \mathrm{mmol})$, Oxidant ( $2 \mathrm{mmol})$, PNO (0.5 mmol) and Co@ $\mathrm{Fe}_{3} \mathrm{O}_{4} / \mathrm{SiO}_{2}(2.5 \mathrm{~mol} \%$ based on Co) at r.t. duration: $3 \mathrm{~h}$. 
with 2 equivalents of the $m$-CPBA which provides moderate source of oxygen for the catalytic reaction (not listed). Consequently, the optimum molar ratio of olefin to oxidant is $1: 2$.

The effect of different axial ligands such as $\mathrm{NH}_{4} \mathrm{OAc}$, PNO, NMNO, Py, MI and imidazole was investigated in the epoxidation of styrene in DCM $/ m$-CPBA system (Table 4). Despite of some reports which stated that axial ligands decrease the yield of reaction, our results showed that some axial ligands obviously increased the yields and shortened the time of reaction. As shown

Table 4. The effect of different axial ligand on the epoxidation of styrene catalyzed by $\mathrm{Co} @ \mathrm{Fe}_{3} \mathrm{O}_{4} / \mathrm{SiO}_{2} \cdot{ }^{\mathrm{a}}$

\begin{tabular}{lcc}
\hline Entry & Axial ligand & Yield (\%) \\
\hline 1 & $\mathrm{NH}_{4} \mathrm{OAc}$ & 15 \\
2 & $\mathrm{Py}$ & 45 \\
3 & $\mathrm{MI}$ & 56 \\
4 & imidazole & 65 \\
5 & NMNO & 80 \\
6 & PNO & 95
\end{tabular}

${ }^{\text {a }}$ Reaction conditions: Styrene ( $\left.1 \mathrm{mmol}\right), m$-CPBA ( $\left.2 \mathrm{mmol}\right)$, axial ligand $(0.5 \mathrm{mmol})$ and $\mathrm{Co} @ \mathrm{Fe}_{3} \mathrm{O}_{4} / \mathrm{SiO}_{2}(2.5 \mathrm{~mol} \%$ based on $\mathrm{Co}$ ) at r.t. in Table 4, poor conversion was observed in the presence of $\mathrm{NH}_{4} \mathrm{OAc}$ (Table 4, entry 1). Using some axial ligand such as Py, MI, imidazole and NMNO, the yield increased up to $45,56,68$ and $80 \%$, respectively (Table 4, entries 2-5). Finally, the best yield was observed in the presence of PNO as axial ligand (Table 4, entry 6, yield: 95\%). Under the same conditions, a new reaction was carried out in the presence of homogeneous $\mathrm{Co}$ (III) complex and styrene was converted to the styrene oxide in $2 \mathrm{~h}$ with $97 \%$ yield (not listed).

The reactions were also performed at $40^{\circ} \mathrm{C}$ and obvious increase in the conversion was observed while the selectivity of the reaction decreased to $85 \%$ (not listed). Therefore, we employed the optimized conditions ( $\left.\mathrm{Co} @ \mathrm{Fe}_{3} \mathrm{O}_{4} / \mathrm{SiO}_{2}, 2.5 \mathrm{~mol} \%\right), m$-CPBA ( $\left.2 \mathrm{mmol}\right)$ and PNO $(0.5 \mathrm{mmol})$ in $3 \mathrm{~mL} \mathrm{DCM}$ at $25^{\circ} \mathrm{C}$ for the conversion of several olefins into the corresponding products. Table 5 lists a group of alkenes that were investigated using $\mathrm{Co} @ \mathrm{Fe}_{3} \mathrm{O}_{4} / \mathrm{SiO}_{2}$. The catalyst showed excellent activity toward alkene oxidation with an average isolation yield of $93 \%$. The yield and selectivity of the products are 91-95\% and $99 \%$, respectively. The efficiency of the catalyst was investigated for the epoxidation of substrates

Table 5. Epoxidation of different alkenes using $m$-CPBA catalyzed by $\mathrm{Co} @ \mathrm{Fe}_{3} \mathrm{O}_{4} / \mathrm{SiO}_{2} \cdot{ }^{\mathrm{a}}$

\begin{tabular}{llllll} 
Entry & Time (h) & Yield $^{\mathrm{b}}(\%)$ & Selectivity $^{\mathrm{c}}(\%)$ & $\mathrm{TON}^{\mathrm{d}}$ & $\mathrm{TOF}^{\mathrm{e}}\left(\mathrm{h}^{-1}\right)$ \\
\hline & 3 & 95 & 3800 & 1266.7 \\
\hline
\end{tabular}

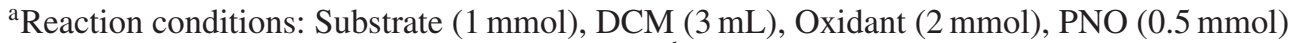
and $\mathrm{Co} @ \mathrm{Fe}_{3} \mathrm{O}_{4} / \mathrm{SiO}_{2}(2.5 \mathrm{~mol} \%$ based on $\mathrm{Co}) .{ }^{\mathrm{b}}$ Determined by GC with a Shimadzu CBP5 column $(30 \mathrm{~m} \times 0.32 \mathrm{~mm} \times 0.25 \mathrm{~mm})$. ${ }^{\mathrm{c}}$ Selectivity based on alkene conversion. ${ }^{\mathrm{d}} \mathrm{TON}=$ $\mathrm{mmol}$ of converted alkene/mmol Co; ${ }^{\mathrm{e}} \mathrm{TOF}=\mathrm{TON} /$ time of reaction. 


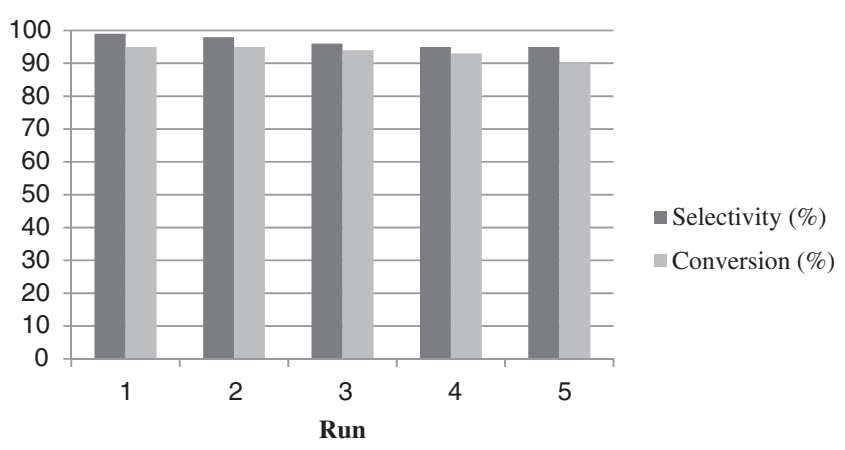

Figure 7. The recycles of the catalyst for the epoxidation styrene with $\mathrm{m}-\mathrm{CPBA}(2 \mathrm{mmol})$ and PNO $(0.25 \mathrm{mmol})$ in DCM (3 mL) catalyzed by $\mathrm{Co} @ \mathrm{Fe}_{3} \mathrm{O}_{4} / \mathrm{SiO}_{2}(2.5 \mathrm{~mol} \%$ based on Co elemental content) at r.t.

having sensitive groups (substrates that have electronwithdrawing group likes 2-cyclohexen-1-one) in which lower yields and selectivity were observed. It could be deduced that $\mathrm{Co} @ \mathrm{Fe}_{3} \mathrm{O}_{4} / \mathrm{SiO}_{2}$ possessed efficient catalytic activity, when the axial ligand PNO was used. The TON and TOF of the reactions are 3600-3800 and 1213.3-1266.7 $\mathrm{h}^{-1}$, respectively. The conditions used for styrene: injector temperature, $220^{\circ} \mathrm{C}$; detector temperature, $250^{\circ} \mathrm{C}$, injection volume, $0.2 \mu \mathrm{L}$, and the oven temperature program was initially started at $150^{\circ} \mathrm{C}$; raised to $220^{\circ} \mathrm{C}$ at $20^{\circ} \mathrm{C} \mathrm{min}^{-1}$; and was set at $220^{\circ} \mathrm{C}$ constantly for $5 \mathrm{~min}$.

To study the reusability of $\mathrm{Co} @ \mathrm{Fe}_{3} \mathrm{O}_{4} / \mathrm{SiO}_{2}$, the catalyst was separated by external magnet, washed with ethanol, dried under vacuum and then subjected to a subsequent round of reaction under the same reaction conditions with no significant loss of activity, which validated its recyclability. The yield and selectivity of the final products were comparable to that of the original one (Figure 7). The leaching of Co ion a into the solution was checked during the reaction by AAS and no significant Co was detected in the filtrate. As shown in the Figure 7, the catalytic activity did not change significantly after five repeated runs (Yield: from 95 to $90 \%$, Selectivity from 99 to $95 \%$ ). The slight decrease in the activity and enantioselectivity of products may be due to the aggregation of $\mathrm{Fe}_{3} \mathrm{O}_{4}$ or the leaching of silica.

\section{Conclusions}

Novel $\mathrm{Co} @ \mathrm{Fe}_{3} \mathrm{O}_{4} / \mathrm{SiO}_{2}$ was synthesized by grafting hemogeneous $\mathrm{Co}$ (III) salen complex onto the $\mathrm{Fe}_{3} \mathrm{O}_{4}$ @ $\mathrm{SiO}_{2} \mathrm{NPs}$. The characterization results confirmed that hemogeneous $\mathrm{Co}$ (III) salen complex has been successfully incorporated onto $\mathrm{Fe}_{3} \mathrm{O}_{4} @ \mathrm{SiO}_{2}$ NPs. This nanocatalyst has strong magnetic responsivity due to a high saturation magnetization value $\left(34.3 \mathrm{emu} \mathrm{g}^{-1}\right)$.
Themagnetic nanocomposite showed excellent catalytic activity toward the epoxidation of alkenes and the best conversion was achieved in the presence of $\mathrm{m}$ CPBA as oxidant and PNO as the axial ligand in DCM. The selectivity of the reaction was also investigated and excellent selectivity was observed (99\%). $\mathrm{Co} @ \mathrm{Fe}_{3} \mathrm{O}_{4} / \mathrm{SiO}_{2}$ showed comparable conversion and selectivity as that of homogeneous counterpart for the epoxidation of several alkenes. In addition, the heterogeneous $\mathrm{Co} @ \mathrm{Fe}_{3} \mathrm{O}_{4} / \mathrm{SiO}_{2}$ is relatively stable and can be reused five times with constant catalytic activity and no metal leaching. Therefore, absence of side reactions, short reaction times, high activity and stability, easy recoverability with external magnet and reusability render it a potentially valuable catalyst for industrial applications.

\section{Acknowledgements}

The authors are grateful to the University of Birjand for financial support.

\section{References}

1. Xia Q H, Ge H Q, Ye C P, Liu Z M and Su K X 2005 Advances in homogeneous and heterogeneous catalytic asymmetric epoxidation Chem. Rev. 1051603

2. Lane B S and Burgess K 2003 Metal-catalyzed epoxidations of alkenes with hydrogen peroxide Chem. Rev. 103 2457

3. Dede B, Karipcin F and Cengiz M 2009 Novel homo- and hetero-nuclear copper (II) complexes of tetradentate schiff bases: Synthesis, characterization, solvent-extraction and catalase-like activity studies $J$. Hazard. Mater. 1631148

4. Ghosh T and Pal S 2015 Synthesis and characterization of dodecahedral cerium (IV) and gadolinium (III) complexes with a tetradentate schiff base J. Chem. Sci. 127 1201

5. Gupta M, Sharma P, Gupta M and Gupta R 2015 Silica functionalized $\mathrm{Cu}$ (II) catalysed selective oxidation of benzyl alcohols using TEMPO and molecular oxygen as an oxidant J. Chem. Sci. 1271485

6. Sandaroos R, Taghi Goldani M, Damavandi S and Mohammadi A 2012 Efficient asymmetric BaeyerVilliger oxidation of prochiral cyclobutanones using new polymer-supported and unsupported chiral Co (salen) complexes J. Chem. Sci. 124871

7. Zhang W, Loebach J L, Wilson S R and Jacobsen E N 1990 Enantioselective epoxidation of unfunctionalized olefins catalyzed by salen manganese complexes $J$. Am. Chem. Soc. 1122801

8. Liao S and List B 2010 Asymmetric counteraniondirected transition-metal catalysis: Enantioselective epoxidation of alkenes with manganese (III) salen phosphate complexes Angew. Chem. Int. Ed. Engl. 49628 
9. Zhang H, Wang Y M, Zhang L, Gerritsen G, Abbenhuis H C, Van Santen R A and Li C 2008 Enantioselective epoxidation of $\beta$-methylstyrene catalyzed by immobilized Mn (salen) catalysts in different mesoporous silica supports J. Catal. 256226

10. Qi B, Wang Y, Lou L, Huang L, Yang Y and Liu S 2013 Solvent-free aerobic oxidation of alcohols over palladium supported on MCM-41 J. Mol. Catal. A: Chem. 37095

11. Kureshy R I, Roy T, Khan N-uH, Abdi S H, Sadhukhan A and Bajaj H C 2012 Reusable chiral macrocyclic Mn (III) salen complexes for enantioselective epoxidation of nonfunctionalized alkenes J. Catal. 28641

12. Maity N C, Abdi S H, Kureshy R I, Khan N-u H, Suresh E, Dangi G P and Bajaj H C 2011 Chiral macrocyclic salen Mn (III) complexes catalyzed enantioselective epoxidation of non-functionalized alkenes using $\mathrm{NaOCl}$ and urea- $\mathrm{H}_{2} \mathrm{O}_{2}$ as oxidants J. Catal. 277123

13. Ren W, Fu X, Bao H, Bai R, Ding P and Sui B 2009 Enantioselective epoxidation of unfunctionalized olefins catalyzed by chiral salen Mn (III) catalyst immobilized on zirconium oligostyrenylphosphonate-phosphate Catal. Commun. 10788

14. Barbaro P and Liguori F 2009 Ion exchange resins: Catalyst recovery and recycle Chem. Rev. 109515

15. Tang Q, Zhang Q, Wu H and Wang Y 2005 Epoxidation of styrene with molecular oxygen catalyzed by cobalt(II)-containing molecular sieves J. Catal. 230384

16. Tang Q, Wang Y, Liang J, Wang P, Zhang Q and Wan $\mathrm{H} 2004 \mathrm{Co}^{2+}$-exchanged faujasite zeolites as efficient heterogeneous catalysts for epoxidation of styrene with molecular oxygen Chem. Commun. 440

17. Sebastian J, Jinka K M and Jasra R V 2006 Effect of alkali and alkaline earth metal ions on the catalytic epoxidation of styrene with molecular oxygen using cobalt (II)-exchanged zeolite X J. Catal. 244208

18. Cui H, Zhang Y, Zhao L and Zhu Y 2011 Adsorption synthesized cobalt-containing mesoporous silica SBA15 as highly active catalysts for epoxidation of styrene with molecular oxygen Catal. Commun. 12417

19. Jinka K M, Pai S M, Newalkar B L, Choudary N V and Jasra R V 2010 Co-SSZ-51 as a catalyst for styrene epoxidation using molecular oxygen Catal. Commun. 11638

20. Jain S and Reiser O 2008 Immobilization of cobalt(II) schiff base complexes on polystyrene resin and a study of their catalytic activity for the aerobic oxidation of alcohols Chem. Sus. Chem. 1534

21. Kowalski G, Pielichowski J and Jasieniak M 2003 Polymer supported cobalt (II) catalysts for alkene epoxidation Appl. Catal. A: Gen. 247295

22. Jin C, Fan W B, Jia Y J, Fan B B, Ma J H and Li R F 2006 Encapsulation of transition metal tetrahydro-schiff base complexes in zeolite $\mathrm{Y}$ and their catalytic properties for the oxidation of cycloalkanes J. Mol. Catal. A: Chem. 24923

23. Bhunia S, Jana S, Saha D, Dutta B and Koner S 2014 Catalytic olefin epoxidation over cobalt(II)-containing mesoporous silica by molecular oxygen in dimethylformamide medium Catal. Sci. Technol. 41820

24. Amarasekara A S, Oki A R, McNeal I and Uzoezie U 2007 One-pot synthesis of cobalt-salen catalyst immobilized in silica by sol-gel process and applications in selective oxidations of alkanes and alkenes Catal. Commun. 81132
25. Ko S and Jang J 2006 A Highly efficient palladium nanocatalyst anchored on a magnetically functionalized polymernanotube support Angew. Chem. Inter. Edit. 457564

26. Polshettiwar V, Luque R, Fihri A, Zhu H, Bouhrara M and Basset J-M 2011 Magnetically recoverable nanocatalysts Chem. Rev. 1113036

27. Cai W and Wan J Q 2007 Facile synthesis of superparamagnetic magnetite nanoparticles in liquid polyols J. Colloid. Interf. Sci. 305366

28. Yan F, Li J, Zhang J J, Liu F Q and Yang W S 2009 Preparation of $\mathrm{Fe}_{3} \mathrm{O}_{4}$ /polystyrene composite particles from monolayer oleic acid modified $\mathrm{Fe}_{3} \mathrm{O}_{4}$ nanoparticles via miniemulsion polymerization J. Nanopart Res. 11289

29. Gu S C, Onishi J Y, Kobayashi Y, Nagao D and Konno M 2005 Preparation and colloidal stability of monodisperse magnetic polymer particles J. Colloid. Interf. Sci. 289419

30. Wang $\mathrm{X}$, Ji $\mathrm{H}$, Zhang $\mathrm{X}$, Zhang $\mathrm{H}$ and Yang $\mathrm{X}$ 2010 Hollow polymer microspheres containing a gold nanocolloid core adsorbed on the inner surface as a catalytic microreactor J. Mater. Sci. 453981

31. Liao Z, Wang H, Lv R, Zhao P, Sun X, Wang S, Su W, Niu R and Chang J 2011 Polymeric liposomes-coated superparamagnetic iron oxide nanoparticles as contrast agent for targeted magnetic resonance imaging of cancer cells Langmuir 273100

32. Weertman J R and Koch C C 2002 In Nanostructured materials: processing, properties and applications (Norwich, NY: William Andrews Publishing)

33. Nakayama H, Arakaki A, Maruyama K and Takeyama H 2003 Single-nucleotide polymorphism analysis using fluorescence resonance energy transfer between DNAlabeling fluorophore, fluorescein isothiocyanate, and DNA intercalator, POPO-3, on bacterial magnetic particles Biotechnol. Bioeng. 8496

34. Jia H F, Zhu G Y and Wang P 2003 Catalytic behaviors of enzymes attached to nanoparticles: The effect of particle mobility Biotechnol. Bioeng. 84406

35. Lei Z, Li Y and Wei X 2008 A facile two-step modifying process for preparation of poly (SStNa)grafted $\mathrm{Fe}_{3} \mathrm{O}_{4} / \mathrm{SiO}_{2}$ particles J. Solid. State. Chem. 181 480

36. Shylesh S, Schunemann V and Thiel W R 2010 Magnetically separable nanocatalysts: Bridges between homogeneous and heterogeneous catalysis Angew. Chem. Inter. Edit. 493428

37. Govan J and Gun'ko Y K 2014 Recent advances in the application of magnetic nanoparticles as a support for homogeneous catalysts Nanomater. 4222

38. Nasseri M A, Allahresani A and Raissi H 2014 Grafting of a chiral Mn (III) complex on graphene oxide nanosheets and its catalytic activity for alkene epoxidation $R S C A d v .426087$

39. Allahresani A and Nasseri M A 2014 A magnetically recyclable $\mathrm{Fe}_{3} \mathrm{O}_{4} @ \mathrm{SiO}_{2} / \mathrm{Mn}$ (III) chiral salen complex as a highly selective and versatile heterogeneous nanocatalyst for the oxidation of olefins and sulfides RSC Adv. 460702

40. Gawande M B, Branco P S and Varma R S 2013 Nanomagnetite $\left(\mathrm{Fe}_{3} \mathrm{O}_{4}\right)$ as a support for recyclable catalysts in the development of sustainable methodologies Chem. Soc. Rev. 423371 
41. Tang J, Dong W J, Wang G, Yao Y Z, Cai L M, Liu Y, Zhao X, Xu J Q and Tan L 2014 Efficient molybdenum (VI) modified Zr-MOF catalysts for epoxidation of olefins RSC Adv. 442977

42. Qi Y, Luan Y, Yu J, Peng X and Wang G 2015 Nanoscaled copper metal-organic framework (MOF) based on carboxylate ligands as an efficient heterogeneous catalyst for aerobic epoxidation of olefins and oxidation of benzylic and allylic alcohols Chem. Eur. J. 21 1589

43. Yu J, Luan Y, Qi Y, Hou J Y, Dong W J, Yang M and Wang G 2014 Hierarchical PS/PANI nanostructure supported $\mathrm{Cu}$ (II) complexes: Facile synthesis and study of catalytic applications in aerobic oxidation $R S C A d v .4$ 55028

44. Yang Y, Hao S, Zhang Y and Kan Q 2011 Oxovanadium (IV) and dioxomolybdenum (VI) salen complexes tethered onto amino-functionalized SBA-15 for the epoxidation of cyclooctene Solid State Sci. 131938

45. Lopez J, Liang S and Bu X R 1998 Unsymmetric chiral salen schiff bases: A new chiral ligand pool from bis-schiff bases containing two different salicylaldehyde units Tetrahedron Lett. 394199

46. Vezin H, Lamour E and Catteau J P 2002 Free radical production by hydroxy-salen manganese complexes studied by ESR and XANES J. Inorg. Biochem. 92177 